\title{
Constraints to native plant species establishment in coastal dune communities invaded by Carpobrotus edulis: Implications for restoration
}

\author{
Ana Novoa a,b,c,*, Luís González ${ }^{\text {a }}$, Lenka Moravcová ${ }^{\mathrm{b}}$, Petr Pyšek ${ }^{\mathrm{b}, \mathrm{d}}$ \\ a Departamento de Bioloxía Vexetal e Ciencia do Solo, Facultade de Bioloxía, Universidade de Vigo, As Lagoas-Marcosende, 36310 Vigo, Spain \\ ${ }^{\mathrm{b}}$ Institute of Botany, Department of Invasion Ecology, Academy of Sciences of the Czech Republic, CZ-252 43 Průhonice, Czech Republic \\ ${ }^{\mathrm{C}}$ Centre for Invasion Biology, Department of Botany and Zoology, Stellenbosch University, Matieland 7602, South Africa \\ ${ }^{\mathrm{d}}$ Department of Ecology, Faculty of Science, Charles University in Prague, Viničná 7, CZ-128 44 Prague, Czech Republic
}

\section{A R T I C L E I N F O}

\section{Article history:}

Received 27 December 2012

Received in revised form 3 April 2013

Accepted 8 April 2013

Available online 1 June 2013

\section{Keywords:}

Enzymes activities

Ecosystem engineers

Invasive species

Malcolmia littorea

Residual effects

\begin{abstract}
A B S T R A C T
Carpobrotus edulis, an alien chamaephyte species from South Africa, severely invades and represents one of the greatest threats to coastal plant biodiversity in regions with Mediterranean climate worldwide. Although actions have been promoted to eliminate it, these efforts have failed to restore dunes to the natural, preinvasion stage.

We tested, by means of field and laboratory experiments, how C. edulis alters soil chemistry by causing residual effects on soil, and examined whether these effects decrease germination, survival and growth of a common native chamaephyte dune species Malcolmia littorea. We also recorded species diversity to find out which species can establish after the removal of the invasive $C$. edulis. To link both measures, we monitored changes in soil characteristics over 1 year after the removal of the invader, by analyzing both soil chemical properties and extracellular enzymes.

C. edulis lowers soil $\mathrm{pH}, \mathrm{Ca}$ and $\mathrm{Na}$ content and increases organic content, salinity and nitrogen and phosphorus concentration. The effects of the invader on the growth of $M$. littorea during the first growing season were very weak, despite strong negative effects in the early stages of this species' population development that decreased total germination and survival.

Overall, the soil characteristics and activity of the microbial community tend to recover back to preinvasion conditions in plots from which $C$. edulis is removed. In contrast, the establishment of native dune vegetation is constrained, as indicated by lower species diversity in restored compared to non-invaded areas. This is because regenerating dunes are occupied by opportunistic ruderal species that compete with native dune plants of conservation value and restrict their establishment.
\end{abstract}

(c) 2013 Elsevier Ltd. All rights reserved.

\section{Introduction}

Invasive plant species are among the most serious environmental problems of today worldwide (Simberloff et al., 2005; Richardson and Pys, 2006; Hulme et al., 2012), including in the Mediterranean region (Hulme et al., 2012; Novoa et al., 2012; Gaertner et al., 2009). Invasive plants affect resident species and communities through a wide range of impacts, including marked reductions in native biodiversity (Pysek and Richardson, 2010; Watling et al., 2011; Gioria et al., 2012; Pyšek et al., 2012a; Pyšek et al., 2012b; Simberloff et al., 2012). This brings about not only ecological effects but also huge economic costs. Despite the assessment of economic consequences of biological invasions

\footnotetext{
* Corresponding author. Permanent address: Departamento de Bioloxía Vexetal e Ciencia do Solo, Facultade de Bioloxía, Universidade de Vigo, As Lagoas-Marcosende, 36310 Vigo, Spain. Tel.: +34 986812 594; fax: +34 986812556.

E-mail addresses: ananovoa@uvigo.es (A. Novoa), luis@uvigo.es (L. González), moravcova@ibot.cas.cz (L. Moravcová), pysek@ibot.cas.cz (P. Pyšek).
}

being still in its infancy, available estimates suggest that the costs are substantial, be it assessed at the global (Pimentel et al., 2005) or regional scale (McConnachie et al., 2012). In Europe, a conservative estimate of costs of biological invasions reaches at least 12.7 billion euro annually (Kettunen et al., 2009), and in Spain alone, 10.1 million euro (Andreu and Vilà, 2007). Therefore the study of invasive species' removal and subsequent restoration of invaded areas has become an important and promising line of research in invasion ecology in the last decade (D'Antonio and Meyerson, 2002; Bakker and Wilson, 2004; Vosse et al., 2008; Selge et al., 2011; Daehler, 2012).

Mediterranean coastal primary dunes are rather homogeneous ecosystems with very little variation in local ecological conditions (Maun, 2009), since they are influenced by the same extreme environmental factors such us salt spray, high winds or high insolation. They are of a high cultural and ecological value, and support many threatened and endemic species ("Council Directive 92/43/EEC, 1992). One of the major invaders of Mediterranean ecosystems is 
a South African succulent species, Carpobrotus edulis, considered by the GEIB (2006) as one of the 20 most aggressive invasive species of coastal dunes. Invasion by C. edulis in coastal habitats (Carranza et al., 2011) has a great impact on community composition, diversity and succession (Donath and Eckstein, 2009) via its modification of soil properties (Novoa et al. 2012; Conser and Connor, 2008). In many parts of the world where $C$. edulis invades natural dune ecosystems (e.g. Southern Europe, California, Australia) removal projects have been carried out in order to restore invaded dunes, but these efforts have failed to restore dunes to the natural, pre-invasion stage (A. Novoa, personal observation). Due to the changes in the soil, ruderal nitrophilous species typically replace the native dune species (Maurel et al., 2009)

Andreu and Vilà (2007) evaluated the ecological success of the manual removal of Carpobrotus species by comparing treated, non-invaded, and invaded plots in southern Spain. Treated plots from which $C$. edulis was removed harbored a higher number of species than invaded plots, especially of annual plants, but both types of plots had the same native plant cover and species diversity. Conser and Connor (2008) examined the residual effects of $C$. edulis on soil and found strong negative effects on the germination, survival and growth of Gilia millefoliata, an annual plant native to the northern coastal region of California. Moreover, it has been shown that the effects of $C$. edulis on $\mathrm{pH}$ and nitrogen compounds persist over time. After Carpobrotus removal, opportunistic ruderal species can have an advantage over native dune species because of the effect of modified soil characteristics, presence of litter, and their ability to compete. Increasing evidence for the residual effects of $C$. edulis invasion, including possible allelopathic effects of its litter (Novoa et al., 2012), suggests that to improve restoration success, it is necessary to understand how this invasive plant affects co-occurring plant species by inducing changes in soil and what the duration of this impact on the invaded ecosystem is. Understanding these effects will help land managers, restoration practitioners, and scientists to more effectively manage and restore dune plant communities and create suitable conditions for native plant species (Cox and Allen, 2008).

In the present paper, we used a combination of: ( $\mathrm{i}$ and ii below) soil and enzymatic activities analysis, (iii) seed and seedling addition field experiments, (iv, v) biodiversity analysis and (vi) laboratory germination experiments to test the following hypothesis: (a) C. edulis has strong effects on chemical properties and microbial activity of soils. (b) These effects persist after the removal of $C$. edulis from invaded plots, creating residual effects of the invasion. (c) Residual effects on soil inhibit re-establishment of native dune plant species after $C$. edulis has been removed. (d) Species composition of communities that establish after the removal of the invader is different from that of natural communities in non-invaded sites that harbour typical native dune species. (e) Changes in soil properties resulting from $C$. edulis invasion promote the emergence of seedlings of ruderal nitrophilous species that establish in removal sites, and by competing with typical native dune species, prevent their establishment.

\section{Materials and methods}

\subsection{Study species}

C. edulis (L.) N. E. Br. (Aizoaceae), native to South Africa, has become one of the most invasive plants of rocky shorelines and dunes. It is one of the most thoroughly studied invasive species (Pysek et al., 2008) and the mechanisms of its invasion and impact have been addressed in a number of studies (Gallagher et al., 1997; Vilà and D'Antonio, 1998; Weber and D'Antonio, 2000; Bartomeus et al., 2008; Novoa et al., 2012). It was originally introduced to
Europe, California and Australia to stabilize coastal sand dunes in the early 20th century (Albert, 1995). C. edulis invades large areas, changing the dynamics of dunes and displacing the local flora. Its growth pattern results in the building of a thick mat of living and dead plant material of up to $40 \mathrm{~cm}$ in depth (D'Antonio and Mahall, 1991).

As a model species to test the effects of $C$. edulis invasion on native dune plants (hypothesis c), we chose Malcolmia littorea (L.) R. $\mathrm{Br}$. (Cruciferae), a perennial plant native to the Atlantic and Mediterranean coasts of Italy and Spain. We chose $M$. littorea as a native dune target species because of its occurrence in coastal habitats (thus in habitats commonly invaded by C. edulis), and because natural populations of $M$. littorea have declined to the point of becoming an endangered species in some areas of north-western Spain as a result of habitat loss due to human activities and biological invasions (Gobierno del principado de Asturias, 1995).

The target native species used to test the competitive effects of opportunistic colonizers (hypothesis (e) above) are the chamaephyte M. littorea and the therophyte Cakile maritima Scop. (Brassicaceae), two species common to coastal dunes, typically thriving in non-invaded vegetation (we refer to these hereafter as 'dune species'), and the hemicryptophytes Scolymus hispanicus L. (Asteraceae) and Dactylis glomerata L. (Poaceae), two species with ruderal life strategies (Grime, 1997) that commonly appear in coastal dunes after the removal of $C$. edulis (referred to as 'ruderal species').

\subsection{Study site}

The experiment was conducted at the coastal dune ecosystem of Punta Ron in O Grove, Pontevedra (42 $\left.29^{\prime} 52.91^{\prime \prime} \mathrm{N} 8^{\circ} 52^{\prime} 59.77^{\prime \prime} \mathrm{W}\right)$, an area with coastal oceanic climate from which $C$. edulis was first reported to occur in Spain in 1900 (GEIB 2006). The annual average temperature is $14.8^{\circ} \mathrm{C}$; it reaches $24.6^{\circ} \mathrm{C}$ in warmer months (JuneSeptember), and $6.4^{\circ} \mathrm{C}$ in colder months (December-March). The average annual rainfall $1263 \mathrm{~mm}$ (O Grove meteorological station, 50-yrs average).

\subsection{Plant material}

Seeds of $M$. littorea and $C$. edulis were collected between 10th September and 10th October 2010 from at least 15 plants from each of 20 different populations of each species, located along $20 \mathrm{~km}$ in Pontevedra Coast, Spain The seeds were stored in the dark at $4{ }^{\circ} \mathrm{C}$ until assay. Seeds were surface-sterilized for $5 \mathrm{~min}$ in $0.1 \%$ sodium hypochlorite, rinsed 3 times in distilled water and dried at room temperature prior to the experiment to avoid fungal attack.

The target seeds for testing the role of ruderal (opportunistic) species (hypothesis e) were provided by Semillas Silvestres S. A. (M. littorea, C. maritima and S. hispanicus) and Semillas Cantueso (D. glomerata).

\subsection{Soil and litter collection}

Soil samples were collected from the above coastal dune location in $\mathrm{O}$ Grove, Pontevedra and located from invaded and non-invaded areas. We randomly established three plots of $0.5 \mathrm{~m} \times 0.5 \mathrm{~m}$ and $10 \mathrm{~m}$ apart in each area (invaded and non-invaded). In each plot, five soil samples were collected from the top $10 \mathrm{~cm}$. In the invaded area, Carpobrotus plants and litter were removed prior to soil collection. In the non-invaded area (practically devoid of litter), soil was collected following the same process. Samples from both sites were sieved ( $2.0 \mathrm{~mm}$ mesh size), homogenized and pooled within samples from invaded and noninvaded plots. 
Litter was collected from an invaded dune in the same area where $C$. edulis was removed 1.5 years ago from the total area of $12,000 \mathrm{~m}^{2}$. Three randomly located plots $(0.5 \mathrm{~m} \times 0.5 \mathrm{~m}, 10 \mathrm{~m}$ apart) were established and five samples were collected from each, homogenized and pooled.

\subsection{Soil analysis}

To reveal possible residual effects on the dune soil produced by the presence of $C$. edulis (hypothesis a), soil from invaded and noninvaded adjacent areas was compared. Elemental soil analysis was performed. Soil $\mathrm{pH}$ was determined in a soil solution rate of 1:2.5 and 1:5 (soil: distilled water) respectively (Guitián and Carballas, 1976; Allen, 1989; Maun, 2009). Chloride was analyzed by the Mohr method (Jander, 1961). Soil moisture was calculated as\% Moisture $=($ Fresh weight - Dry weight $) /($ Fresh weight $)$ by drying three replicate sub-samples of each soil sample at $70^{\circ} \mathrm{C}$ for $48 \mathrm{~h}$. The total C content was estimated after combustion at $1200^{\circ} \mathrm{C}$ of $0.1 \mathrm{~g}$ of soil, previously powdered in LECO-CNS 2000 analyzer (Analíticos, 1973). The percentage of organic matter was calculated by multiplying the percentage of total carbon by the Van Bemmelen factor of 1.724 (Analíticos, 1973). Nitrogen compounds such as ammonium, nitrate and nitrite were analyzed using the method described by Kempers (1974). The Ca, Mg and Na contents were extracted using a combined $\mathrm{HCl}-\mathrm{HNO}_{3}$ method prior to spraying and combustion ( $3 \mathrm{~h}, 550^{\circ} \mathrm{C}$ ) (Sumner and Miller, 1996). Quantification was then carried out by inductively coupled plasma optical emission spectroscopy (ICP-OES) (Saña Vilaseca, 1996). The available $P$ was extracted using the method described by Jakmunee and Junsomboon (2009) for colorimetric determination using the method of Bray and Kurtz (1945).

\subsection{Field experimental design}

Following Conser and Connor's (2008) design, in November 2010 we delimited nine plots $(1.5 \mathrm{~m} \times 0.5 \mathrm{~m})$ where $C$. edulis was present and nine non-invaded adjacent plots with native vegetation in $\mathrm{O}$ Grove (in order to test hypothesis $\mathrm{c}$ and $\mathrm{d}$ ). We cleared all aboveground biomass and litter from each plot. To prevent the attack of mammal herbivores, plots were protected with metal meshwork. Plots were divided into three subplots of $0.5 \mathrm{~m} \times 0.5 \mathrm{~m}$, and each of these was subjected to a different treatment: (i) sown with $M$. littorea seeds, (ii) transplanted with $M$. littorea seedlings, and (iii) no addition of the native species to reveal the natural colonization.

In treatment (i) the sown seeds were divided into five groups of 10 seeds each. Each group was protected with a plastic tube of $12 \mathrm{~cm}$ in diameter to prevent seed from being carried away by water. Seeds were sown on 18 November 2010. Once the seeds germinated, the plastic tubes and some seedlings were removed (on 11 February 2011), leaving one seedling in each of the five groups in each subplot, in order to prevent plants from competing for space. In treatment (ii), five seedlings of $M$. littorea were transplanted to each subplot in February 2011, on the same day as seedlings in the sown plots were thinned.

In sown plots, the number of germinated seeds was recorded weekly for 3 months. The recorded data were used to calculate two indices commonly used to describe the pattern of germination (Hussain et al., 2008): total germination rate (Gt), and the cumulative rate of germination (AS).

In both sown and transplant plots, we measured life history characters (survival, leaf number, diameter and shoot length) of five plants from each plot every week since February 2011. At the end of the experiment (1 April 2011) we recorded root and shoot length of all the plants.

\subsection{Plant species diversity}

At the end of the experiment, plant species diversity in control plots (iii) was recorded in order to test hypothesis $d$. The species recorded were categorized according to their typical habitat into species confined to dunes and ruderal species (Gordon, 1998).

Plant diversity was measured by using (i) Simpson's diversity index $\left(\lambda=\sum p_{i}^{2}\right)$ that takes into account the number of species present, as well as their relative abundances; (ii) Shannon index $\left(H \prime=-\sum p_{i} \log p_{i}\right)$, that takes into account the number of species and their evenness; and (iii) Margalef index $\left(d=(R-1) / \ln p_{i}\right)$, based on a numerical distribution of individuals of different species depending on the number of individuals in the sample (Magurran, 1988 ); where $R$ is the number of species and $p_{i}$ is the proportion of individuals that belong to the species $i$. An increase in the values of the Shannon and Margalef indices is usually interpreted as an improvement in the state of the system, while high values of Simpson index indicate the opposite (Salas et al., 2004).

\subsection{Role of ruderal species}

To test hypothesis e, seeds of M. littorea, C. maritima, D. glomerata and S. hispanicus were sowed on Petri dishes. Fourteen seeds were placed on a dish, either in pure cultures of each species, or simulating competition between dune and ruderal species with seven seeds of each group in all possible combinations $(M$. littorea $+D$. glomerata, M. littorea $+S$. hispanicus, C. maritima $+D$. glomerata and C. maritima + S. hispanicus). Petri dishes were filled with $2 \mathrm{~g}$ of soil from both non-invaded and invaded areas. When removal projects are carried out, the plants of $C$. edulis are removed from the dune ecosystem but their litter usually remains in place. Therefore, to test the effect of Carpobrotus litter, another set of Petri dishes was filled with $2 \mathrm{~g}$ of soil from invaded areas and $10 \mathrm{~g}$ of Carpobrotus litter. In total, 120 Petri dishes were established: 8 target species combinations ( 4 pure cultures +4 combinations of dune and ruderal species) $\times 3$ soil types (non-invaded, invaded, invaded + litter $) \times 5$ replicates.

The Petri dishes were placed in germination chambers with periods of $12 \mathrm{~h}$ of light/dark and $25^{\circ} \mathrm{C} / 15^{\circ} \mathrm{C}$ (temperatures and light regimes similar to those in the field during autumn, when seeds germinate in the field), and watered with $4 \mathrm{~mL}$ of distilled water once a week. The number of germinated seeds was recorded every 2 days for 3 weeks. At the end of the experiment, radicle and shoot length of three random seedlings per dish were measured using calipers. Total germination rate $(\mathrm{Gt})$ and the cumulative rate of germination (As) were calculated using germination data.

\subsection{Dune restoration}

In October 2011 ( 1 year after the removal of $C$. edulis), to test hypothesis b, soil was collected in O Grove, Pontevedra, from invaded, non-invaded and previously invaded areas. Soil samples were collected in the same way as described above (see Soil and litter collection) and analyzed for chemical properties (see Soil analysis). In addition, we assayed the following enzymes: $\beta-1,4-$ glucosidase (EC 3.2.1.21), urease (EC 3.5.1.5) and phosphatase (EC 3.1.3.1.). We analyzed these enzymes because they are key stages in the carbon, nitrogen and phosphate cycle, respectively. The principal function of $\beta-1,4-G$ lucosidase (BG) is hydrolysis of cellobiose to glucose, but it is active against other carbohydrates as well. Therefore, BG is one of the most important enzymes involved in the mineralization of Carbon (Ljungdahl and Eriksson, 1985). Urease catalyzes the hydrolysis of urea to $\mathrm{NH}_{3}$ and $\mathrm{CO}_{2}$. The content of organic matter does not seem responsible for the increase in urease activity, but the type of organic matter (Pancholy and Rice, 1973). 
Phosphatases are a large group of enzymes that catalyze the hydrolysis of esters and anhydrides of phosphoric acid (Speir and Ross, 1978). The phosphatase activity are influenced by various soil properties, soil-microorganism interactions, vegetation cover, leachate inputs and the presence of inhibitors or activators (Stege et al., 2009). We used the methods of Allison and Vitousek (2005), Kandeler and Gerber (1988) and Tabatabai and Bremner (1969) for the analysis of glucosidase, urease and phosphatase activities respectively.

There were five analytical replicates and five sample controls of each treatment. All the enzyme activities were expressed as $\mu \mathrm{mol}$ soil converted per hour and grams of dry soil.

As recommended by German et al. (2011), we ran the enzyme assays at the environmental $\mathrm{pH}$. Assays at the soil $\mathrm{pH}$ provide a measure of the potential activity under field conditions (Turner, 2010). Thus, in this paper, we do not refer to acid or alkaline phosphatase, but to phosphatase activity at soil $\mathrm{pH}$.

\subsection{Statistical analysis}

Data were analyzed with the statistical program IBM - SPSS Statistics 19 (SPSS, Inc., Chicago, IL). The first exploratory analysis of the data was performed using box plots to detect and remove outliers.

The data on soil analysis; germination, survival and growth of $M$. littorea; diversity indexes and dune restoration (hypotheses a, b, c and d) were analyzed by Student's $t$ test since we compared two treatments (invaded vs non-invaded or Malcolmia from seeds vs from seedlings). The plant diversity data were analyzed by chi-square analysis (hypothesis d). To test the role of 'species strategy' (ruderal vs dune species, hypothesis e), a two-way ANOVA was performed on all soil types and species pooled, with 'soil type' and 'species strategy as main effects Also, a one-way ANOVA was performed to test the effect of competition (pure cultures and two mixtures) and soil effect (non-invaded, invaded and invaded + litter).

\section{Results}

\subsection{Soil analysis}

Non-invaded plots differed in all but three chemical soil properties analyzed from those invaded by $C$. edulis (Table 1 ). The $\mathrm{pH}$ in invaded plots was significantly lower (by $24 \%$ ).

Overall, the content of sodium chloride (29\%), carbon and organic matter $(2 \times)$, soil moisture $(8 \times)$ and available phosphorus $(2 \times)$ were higher in invaded soil, while the content of nitrites (42\%), sodium (19\%) and calcium $(4 \times)$ were higher in non-invaded plots. The two types of plots did not significantly differ in nitrate, ammonium and $\mathrm{Mg}$ content (Table 1).

\subsection{Germination, survival and growth of M. littorea}

Both total (Gt) and cumulative (AS) germination of $M$. littorea on soil from invaded plots was reduced to about a half of values recorded on that from non-invaded plots (Fig. 1A). Shoot and root lengths of seedlings grown from seed did not significantly differ between both types of soil (Fig. 1A) and the same was true for transplanted seedlings (Fig. 1B). Seedlings of $M$. littorea sown in non-invaded soils had survival rates 15 times higher than those sown on C. edulis-invaded soils (Fig. 1A), but transplanted seedlings did not significantly differ in the rate of survival (Fig. 1B).

The effect of soil type on the establishment of $M$. littorea seedlings was manifest until the fourth week of growth, with seedlings grown from seed on non-invaded soil producing more leaves than
Table 1

Student's t-test results testing the physical and chemical properties of dune sand compared for plots invaded by Carpobrotus edulis and non-invaded plots. ${ }^{* *}$ Indicates significant differences at $5 \%$ level between invaded and native areas., n.s. - not significantly different. Numbers in parentheses indicate the standard error.

\begin{tabular}{|c|c|c|c|}
\hline \multirow[t]{2}{*}{ Characteristics } & \multicolumn{3}{|c|}{ Soil treatment } \\
\hline & Invaded & Non-invaded & Significance \\
\hline $\mathrm{pH}$ & $\begin{array}{l}6.99 \\
(0.16)\end{array}$ & $\begin{array}{l}9.15 \\
(0.05)\end{array}$ & $* *$ \\
\hline $\begin{array}{l}\text { Salinity } \\
\left(\mathrm{mgNaCl} \mathrm{g}^{-1}\right)\end{array}$ & $\begin{array}{l}0.75 \\
(0.03)\end{array}$ & $\begin{array}{l}0.52 \\
(0.04)\end{array}$ & $* *$ \\
\hline $\begin{array}{l}\text { Moisture } \\
(\%)\end{array}$ & $\begin{array}{l}0.74 \\
(0.004)\end{array}$ & $\begin{array}{l}0.09 \\
(0.002)\end{array}$ & $* *$ \\
\hline $\begin{array}{l}\text { Organic matter } \\
\left(\mathrm{g} \mathrm{kg}^{-1}\right)\end{array}$ & $\begin{array}{l}6.32 \\
(0.35)\end{array}$ & $\begin{array}{l}3.02 \\
(0.21)\end{array}$ & ** \\
\hline $\begin{array}{l}P_{\text {available }} \\
\left(\mathrm{g} \mathrm{kg}^{-1}\right)\end{array}$ & $\begin{array}{l}38.37 \\
(1.42)\end{array}$ & $\begin{array}{l}22.08 \\
(0.48)\end{array}$ & $* *$ \\
\hline $\begin{array}{l}\mathrm{NH}_{4}^{+} \\
\left(\mathrm{g} \mathrm{kg}^{-1}\right)\end{array}$ & $\begin{array}{l}8.4 \\
(1.03)\end{array}$ & $\begin{array}{l}6.93 \\
(0.55)\end{array}$ & n.s. \\
\hline $\begin{array}{l}\mathrm{NO}_{3}^{-} \\
\left(\mathrm{g} \mathrm{kg}^{-1}\right)\end{array}$ & $\begin{array}{l}1.1 \\
(0.43)\end{array}$ & $\begin{array}{l}0.87 \\
(0.20)\end{array}$ & n.s. \\
\hline $\begin{array}{l}\mathrm{NO}_{2}^{-} \\
\left(\mathrm{g} \mathrm{kg}^{-1}\right)\end{array}$ & $\begin{array}{l}0.07 \\
(0.00)\end{array}$ & $\begin{array}{l}0.12 \\
(0.01)\end{array}$ & $* *$ \\
\hline $\begin{array}{l}\mathrm{Na}^{+} \\
\left(\mathrm{g} \mathrm{kg}^{-1}\right)\end{array}$ & $\begin{array}{l}0.21 \\
(0.01)\end{array}$ & $\begin{array}{l}0.17 \\
(0.01)\end{array}$ & ** \\
\hline $\begin{array}{l}\mathrm{Ca}^{++} \\
\left(\mathrm{g} \mathrm{kg}^{-1}\right)\end{array}$ & $\begin{array}{l}9.2 \\
(0.23)\end{array}$ & $\begin{array}{l}2.4 \\
(0.10)\end{array}$ & $* *$ \\
\hline $\begin{array}{l}\mathrm{Mg}^{++} \\
\left(\mathrm{g} \mathrm{kg}^{-1}\right)\end{array}$ & $\begin{array}{l}0.29 \\
(0.12)\end{array}$ & $\begin{array}{l}0.28 \\
(0.14)\end{array}$ & n.s. \\
\hline
\end{tabular}

those growing on soil from invaded plots, but by week five this effect disappeared (Fig. 2A). Seedlings did not differ in shoot length (Fig. 2A) and those growing from transplants were not affected by soil type in either of the two parameters measured (Fig. 2B).

\subsection{Plant species diversity}

After removal of all plant species from non-invaded and C. edulis-invaded plots, many plant species are able to establish in the former. In contrast, only a few typical dune species (such as the geophytes Calystegia soldanella (L.) R.Br. ex Roem. and Schult. and Pancratium maritimum L., and the chamaephyte Euphorbia paralias L.) are able to establish in areas previously invaded by C. edulis (Fig. 3).

One year after the removal of vegetation cover, the number of dune species and their abundance measured by the number of individuals was higher in non-invaded than invaded plots, but the opposite was true for ruderal species (Fig. 4). This indicates that invaded plots are recolonized by fewer but more abundant species and corresponds to significantly higher species diversity $(P \leqslant 0.01$, $)$ in non-invaded areas as reflected by all three indices: Shannon (2.0 and 1.2 for non-invaded and invaded plots, respectively), Simpson (5.8 and 3.0) and Margaleff (2.6 and 1.1). With 0.20 and $0.14,0.05$ and $0.21,0.22$ and 0.13 standard errors respectively.

\subsection{Species strategy: dune vs ruderal species}

Germination $(P=0.010)$ and radicle growth $(P=0.026)$ of target species showed an interaction between plant species strategy and soil treatment $(P \leqslant 0.05$, two-way ANOVA). Table 2 shows the effect of soil treatment on germination and early growth of each target species; these effects are species-dependent. Germination rate in M. littorea was greatly enhanced (by $173 \%$ ) on C. edulis-affected soil with litter and the same was true for total germination of $C$. maritima (by $150 \%$ ). Shoot growth of $M$. littorea was also stimulated in invaded soil plus litter treatment (by $172 \%$ ) but not in C. maritima. Opposite to this, invaded soil with litter reduced radicle 
(A) Sown seed

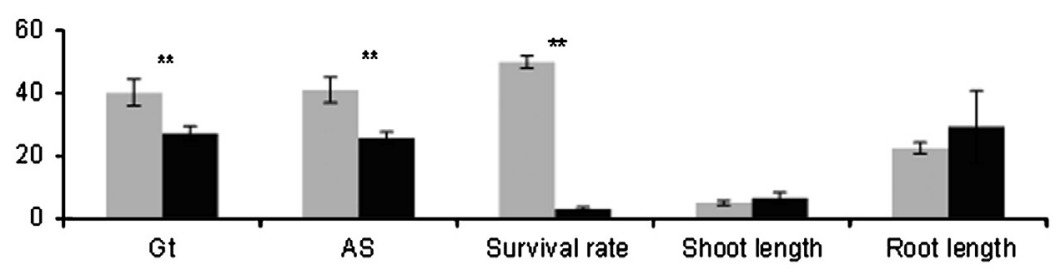

(B) Planted seedlings

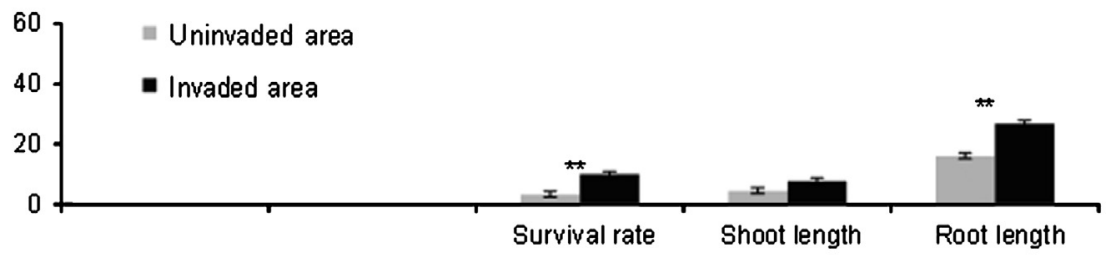

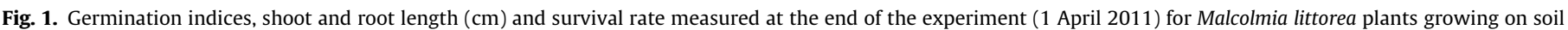

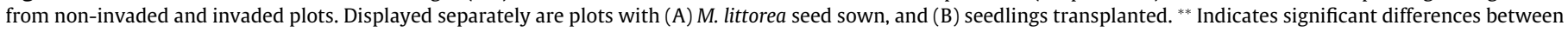
soil from invaded and non-invaded areas at 5\% level, tested by Student's t-test. Error bars denote standard errors.

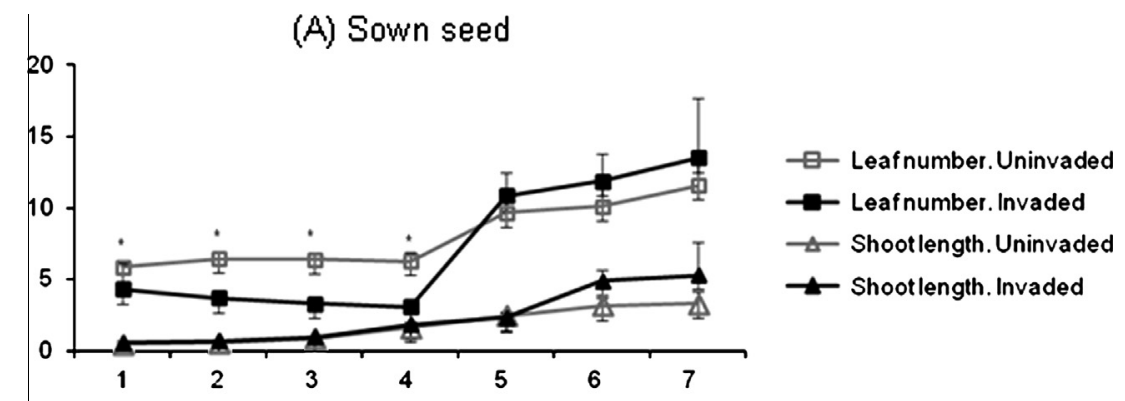

(B) Planted seedlings
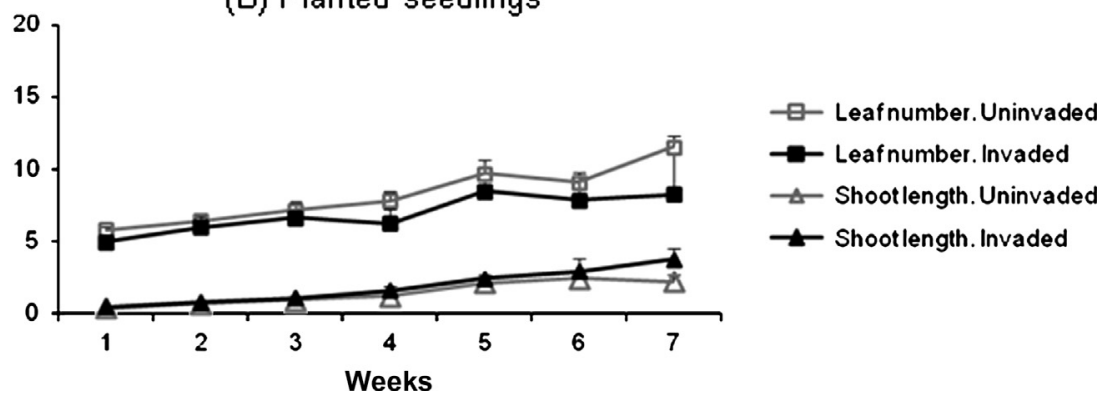

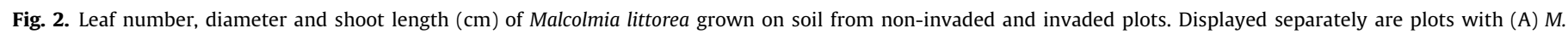

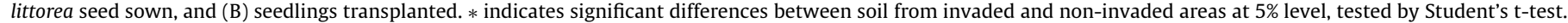
Error bars denote standard errors.

growth of both $M$. littorea and C. maritima, by $43 \%$ and $15 \%$, respectively, indicating that the establishment of dune species is constrained by $C$. edulis residuals in soil. Ruderal species did not respond to soil treatments (Table 2 ).

Competition between the dune species M. littorea and two ruderal species $S$. hispanicus and D. glomerata was more intense on soil affected by $C$. edulis (Table 3 ). On soil from non-invaded plots, the only negative effect experienced by $M$. littorea was that on radicle growth in competition with $D$. glomerata. In the treatments with soil and/or litter from invaded plots, germination and growth of $M$. littorea was often inhibited by competition, with stronger effects resulting from competition with $S$. hispanicus on invaded soil with litter where the dune species' germination was reduced by
$58 \%$ (Gt) and $73 \%$ (AS), shoot growth by $45 \%$ and radicle growth by $20 \%$. On invaded soil without litter, the same significant effects of competition with $S$. hispanicus were found, but the reduction was less pronounced and the effect on germination rate not significant. $D$. glomerata had a significant negative effect only on radicle growth of $M$. littorea, reducing it by $14 \%$ on invaded soil and $20 \%$ if combined with litter (Table 3).

\subsection{Dune restoration}

The results of soil analyses indicated significant differences $(P \leqslant 0.05)$ between non-invaded areas, those invaded by $C$. edulis, and those restored, one year after the removal of $C$. edulis. 


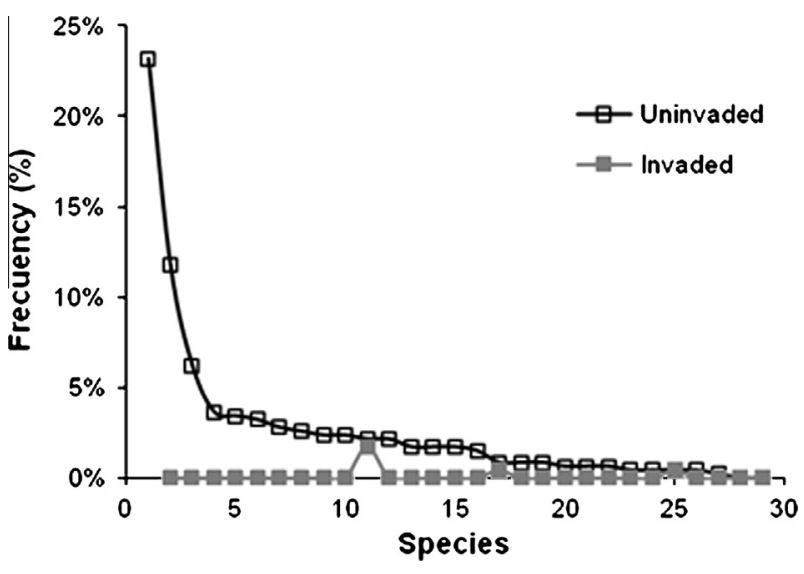

Fig. 3. Frequency of dune species (number of individuals of each dune species/total number of individuals) recorded in non-invaded and invaded areas one year after the removal of vegetation cover.

\section{(A) Number of individuals}

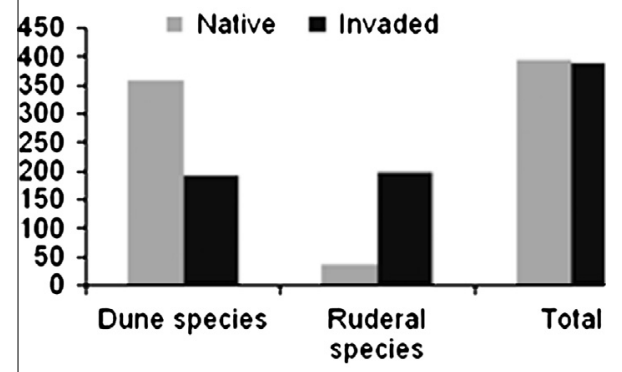

(B) Number of species

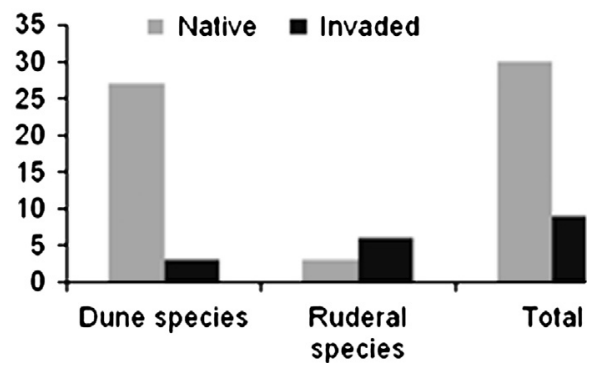

Fig. 4. Number of individuals (A) and species (B) recorded in non-invaded and invaded areas one year after the complete removal of vegetation cover. Values pooled from all plots in each category.
Generally, there is an obvious tendency for restored soils to follow a trajectory toward pre-invasion conditions as indicated by most values being intermediate between those for non-invaded and invaded soils. For some parameters (salinity, $\mathrm{Na}$ and $\mathrm{Mg}$ contents), the values for restored areas do not differ from those found in non-invaded soils, while for others (e.g. moisture, phosphorus), full restoration is likely to be a longer process; some properties, such as $\mathrm{pH}$, organic matter contents or nitrates, remain at the same level as in invaded plots 1 year after restoration (Table 4 ).

Urease and phosphatase activities were higher in invaded soils than on restored and non-invaded soils. Glucosidase activity did not differ among non-invaded, restored an invaded soils (Fig. 5).

\section{Discussion}

\subsection{Effects of C. edulis invasion on dune soil}

It has been shown that following the invasion of $C$. edulis in coastal habitats, some soil properties such as organic matter content and $\mathrm{pH}$ are modified (Conser and Connor, 2008). Lichter (1998), in a study using a chronosequence of differently aged dunes, reported a reduction in $\mathrm{pH}$ from 8.5 to 4.3 after 400 years of dune stabilization. Since $C$. edulis stabilizes the dunes, the decrease in $\mathrm{pH}$ following invasion was expected. The mechanism of acidification is that $C$. edulis takes up large quantities of calcium from the soil (Lichter, 1998; Hartmann, 2002), resulting in lower $\mathrm{Ca}^{2+}$ and $\mathrm{Mg}^{2+}$ values and an increase in hydrogen ions $\left(\mathrm{H}^{+}\right)$in the soil exchange complex, which decreases the $\mathrm{pH}$. Our results support the observation of Lichter (1998): cation values in non-invaded soils are very high but lower in invaded soils, where the $\mathrm{pH}$ was two points lower.

In highly porous sandy soils, moisture is one of the most limiting factors for plant growth. After rainfall, these soils drain much of the water and evaporation and wind in the dune systems also causes them to lose substantial amounts of water (Maun, 2009). We found low soil moisture in non-invaded areas, while where $C$. edulis invaded, the values were higher. One of the reasons for this increase could be the attenuation of temperature and radiation levels due to the presence of $C$. edulis, and wind reduction on invaded areas compared to open ones (Lortie and Cushman, 2007). Moreover, the levels of moisture depend on the higher organic moisture content on invaded areas, as it was indicated by both Gooding (1947), and Konova (1966).

Plant growth and development are adversely affected by salinity, the major environmental stress factor that limits plant production (Läuchli and Grattan, 2007). On the coast, the most important salt ions are $\mathrm{Na}+$ and $\mathrm{Cl}^{-}$. The increase in salinity observed in the

Table 2

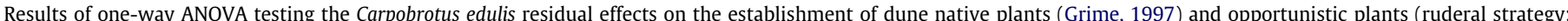

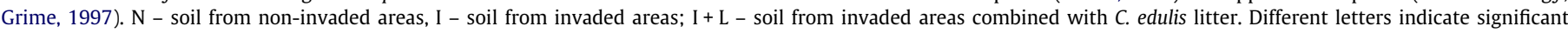

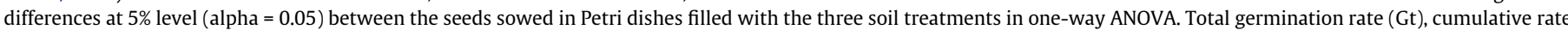
of germination (AS), shoot length and radicle length at the end of the experiment are shown. Numbers in parentheses indicate the standard error.

\begin{tabular}{|c|c|c|c|c|c|c|c|c|c|c|c|c|}
\hline \multirow[t]{3}{*}{ Characteristics } & \multicolumn{6}{|c|}{ Typical dune species (stress tolerator) } & \multicolumn{6}{|c|}{ Opportunistic dune species (ruderal plants) } \\
\hline & \multicolumn{3}{|c|}{ Malcomia littorea } & \multicolumn{3}{|c|}{ Cakile maritima } & \multicolumn{3}{|c|}{ Scolymus hispanicus } & \multicolumn{3}{|c|}{ Dactylis glomerata } \\
\hline & $\mathrm{N}$ & I & $\mathrm{I}+\mathrm{L}$ & $\mathrm{N}$ & I & $\mathrm{I}+\mathrm{L}$ & $\mathrm{N}$ & I & $\mathrm{I}+\mathrm{L}$ & $\mathrm{N}$ & I & $\mathrm{I}+\mathrm{L}$ \\
\hline Gt & $\begin{array}{l}19.6 \\
(3.4)\end{array}$ & $\begin{array}{l}19.0 \\
(6.1)\end{array}$ & $\begin{array}{l}21.4 \\
(2.9)\end{array}$ & $\begin{array}{l}15.0^{\mathrm{b}} \\
(2.8)\end{array}$ & $\begin{array}{l}22.5^{\mathrm{ab}} \\
(8.5)\end{array}$ & $\begin{array}{l}37.5^{\mathrm{a}} \\
(7.5)\end{array}$ & $\begin{array}{l}55.3 \\
(5.3)\end{array}$ & $\begin{array}{l}53.5 \\
(4.6)\end{array}$ & $\begin{array}{l}46.4 \\
(8.5)\end{array}$ & $\begin{array}{l}54.7 \\
(8.5)\end{array}$ & $\begin{array}{l}48.2 \\
(7.3)\end{array}$ & $\begin{array}{l}35.7 \\
(6.5)\end{array}$ \\
\hline AS & $\begin{array}{c}0.15^{\mathrm{b}} \\
(0.06)\end{array}$ & $\begin{array}{r}0.29^{\mathrm{b}} \\
(0.05)\end{array}$ & $\begin{array}{r}0.41^{\mathrm{a}} \\
(0.05)\end{array}$ & $\begin{array}{c}0.14 \\
(0.05)\end{array}$ & $\begin{array}{c}0.16 \\
(0.05)\end{array}$ & $\begin{array}{c}0.24 \\
(0.06)\end{array}$ & $\begin{array}{c}0.91 \\
(0.10)\end{array}$ & $\begin{array}{c}0.81 \\
(0.06)\end{array}$ & $\begin{array}{c}0.72 \\
(0.10)\end{array}$ & $\begin{array}{c}0.51 \\
(0.10)\end{array}$ & $\begin{array}{c}0.42 \\
(0.06)\end{array}$ & $\begin{array}{c}0.23 \\
(0.06)\end{array}$ \\
\hline Shoot growth $(\mathrm{cm})$ & $\begin{array}{c}0.18^{\mathrm{b}} \\
(0.01)\end{array}$ & $\begin{array}{c}0.24^{\mathrm{b}} \\
(0.02)\end{array}$ & $\begin{array}{c}0.49^{\mathrm{a}} \\
(0.05)\end{array}$ & $\begin{array}{c}1.50 \\
(0.20)\end{array}$ & $\begin{array}{c}1.90 \\
(0.40)\end{array}$ & $\begin{array}{c}1.80 \\
(0.20)\end{array}$ & $\begin{array}{c}0.27 \\
(0.01)\end{array}$ & $\begin{array}{c}0.28 \\
(0.01)\end{array}$ & $\begin{array}{c}0.32 \\
(0.03)\end{array}$ & $\begin{array}{c}2.49 \\
(0.15)\end{array}$ & $\begin{array}{c}2.72 \\
(0.12)\end{array}$ & $\begin{array}{c}2.91 \\
(0.23)\end{array}$ \\
\hline Radicle growth $(\mathrm{cm})$ & $\begin{array}{l}2.65^{\mathrm{a}} \\
(0.2)\end{array}$ & $\begin{array}{l}2.44^{\mathrm{ab}} \\
(0.5)\end{array}$ & $\begin{array}{l}1.50^{\mathrm{b}} \\
(0.2)\end{array}$ & $\begin{array}{c}4.1^{\mathrm{a}} \\
(1.3)\end{array}$ & $\begin{array}{l}3.9^{\mathrm{a}} \\
(0.8)\end{array}$ & $\begin{array}{l}3.5^{\mathrm{b}} \\
(0.7)\end{array}$ & $\begin{array}{c}8.9 \\
(0.7)\end{array}$ & $\begin{array}{r}7.01 \\
(0.5)\end{array}$ & $\begin{array}{r}7.72 \\
(0.8)\end{array}$ & $\begin{array}{c}5.72 \\
(0.6)\end{array}$ & $\begin{array}{r}6.21 \\
(0.4)\end{array}$ & $\begin{array}{c}6.02 \\
(0.7)\end{array}$ \\
\hline
\end{tabular}


Table 3

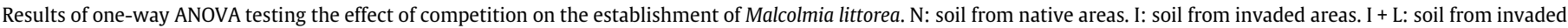

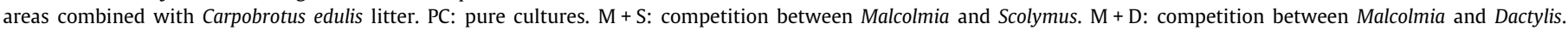
Different letters indicate significant differences at $5 \%$ level between seeds growing with or without competition. Numbers in parentheses indicate the standard error.

\begin{tabular}{|c|c|c|c|c|c|c|c|c|c|}
\hline \multirow[t]{3}{*}{ Characteristic } & \multicolumn{9}{|c|}{ Soil treatment } \\
\hline & \multicolumn{3}{|c|}{ Non-invaded area $(\mathrm{N})$} & \multicolumn{3}{|c|}{ Invaded area (I) } & \multicolumn{3}{|c|}{ Invaded area + Litter $(\mathrm{I}+\mathrm{L})$} \\
\hline & PC & $M+S$ & $M+D$ & PC & $M+S$ & $M+D$ & PC & $M+S$ & $M+D$ \\
\hline Gt & $\begin{array}{l}19.6 \\
(3.4)\end{array}$ & $\begin{array}{l}20.7 \\
(3.6)\end{array}$ & $\begin{array}{l}18.2 \\
(4.9)\end{array}$ & $\begin{array}{l}19.0^{\mathrm{a}} \\
(6.2)\end{array}$ & $\begin{array}{l}10.7^{\mathrm{b}} \\
(6.8)\end{array}$ & $\begin{array}{l}14.2^{\mathrm{a}} \\
(5.8)\end{array}$ & $\begin{array}{l}21.4^{\mathrm{a}} \\
(2.9)\end{array}$ & $\begin{array}{c}9.1^{\mathrm{b}} \\
(4.1)\end{array}$ & $\begin{array}{l}19.5^{a b} \\
(6.2)\end{array}$ \\
\hline AS & $\begin{array}{c}0.29 \\
(0.05)\end{array}$ & $\begin{array}{c}0.34 \\
(0.20)\end{array}$ & $\begin{array}{c}0.24 \\
(0.10)\end{array}$ & $\begin{array}{c}0.14 \\
(0.06)\end{array}$ & $\begin{array}{c}0.09 \\
(0.05)\end{array}$ & $\begin{array}{c}0.13 \\
(0.06)\end{array}$ & $\begin{array}{r}0.41^{\mathrm{a}} \\
(0.05)\end{array}$ & $\begin{array}{c}0.11^{\mathrm{b}} \\
(0.07)\end{array}$ & $\begin{array}{r}0.34^{\mathrm{a}} \\
(0.13)\end{array}$ \\
\hline Shoot growth (cm) & $\begin{array}{c}0.18 \\
(0.01)\end{array}$ & $\begin{array}{c}0.20 \\
(0.00)\end{array}$ & $\begin{array}{c}0.20 \\
(0.00)\end{array}$ & $\begin{array}{r}0.24^{\mathrm{a}} \\
(0.02)\end{array}$ & $\begin{array}{c}0.16^{\mathrm{b}} \\
(0.03)\end{array}$ & $\begin{array}{r}0.23^{\mathrm{a}} \\
(0.03)\end{array}$ & $\begin{array}{r}0.49^{\mathrm{a}} \\
(0.05)\end{array}$ & $\begin{array}{c}0.27^{\mathrm{b}} \\
(0.07)\end{array}$ & $\begin{array}{c}0.47^{\mathrm{a}} \\
(0.10)\end{array}$ \\
\hline Radicle growth (cm) & $\begin{array}{l}2.65^{a} \\
(0.2)\end{array}$ & $\begin{array}{c}2.4^{\mathrm{ab}} \\
(0.3)\end{array}$ & $\begin{array}{l}1.5^{\mathrm{b}} \\
(0.3)\end{array}$ & $\begin{array}{l}2.44^{\mathrm{a}} \\
(0.5)\end{array}$ & $\begin{array}{c}2.0^{\mathrm{b}} \\
(0.7)\end{array}$ & $\begin{array}{l}2.1^{\mathrm{b}^{\prime}} \\
(0.9)\end{array}$ & $\begin{array}{r}1.5^{\mathrm{a}} \\
(0.2)\end{array}$ & $\begin{array}{c}1.2^{\mathrm{b}} \\
(0.1)\end{array}$ & $\begin{array}{c}1.2^{\mathrm{b}} \\
(0.1)\end{array}$ \\
\hline
\end{tabular}

Table 4

Student's $t$-test results testing the chemical properties of soils from invaded, noninvaded and restored areas one year after the removal of Carpobrotus edulis. Different letters within rows indicate significantly different means at $1 \%$ level. Numbers in parentheses indicate the standard error.

\begin{tabular}{|c|c|c|c|}
\hline \multirow[t]{2}{*}{ Property } & \multicolumn{3}{|c|}{ Soil treatment (area) } \\
\hline & Invaded & Restored & Non-invaded \\
\hline \multirow[t]{2}{*}{$\mathrm{pH}$} & $8.37^{\mathrm{b}}$ & $8.2^{\mathrm{b}}$ & $8.86^{\mathrm{a}}$ \\
\hline & $(0.06)$ & $(0.03)$ & $(0.03)$ \\
\hline Salinity & $61.69^{a}$ & $50.77^{b}$ & $45.36^{\mathrm{b}}$ \\
\hline$\left(\mathrm{mgNaCl} \mathrm{g}^{-1}\right)$ & $(3.7)$ & $(1.8)$ & $(3.6)$ \\
\hline Moisture & $15.16^{\mathrm{a}}$ & $8.17^{\mathrm{b}}$ & $4.74^{\mathrm{c}}$ \\
\hline (\%) & $(1.2)$ & $(0.9)$ & $(0.5)$ \\
\hline Organic matter & $8.25^{\mathrm{a}}$ & $5.72^{\mathrm{a}}$ & $2.98^{\mathrm{b}}$ \\
\hline$\left(\mathrm{g} \mathrm{kg}^{-1}\right)$ & $(1.3)$ & $(0.9)$ & $(0.5)$ \\
\hline$P_{\text {available }}$ & $48.8^{a}$ & $24.74^{\mathrm{b}}$ & $21.71^{\mathrm{c}}$ \\
\hline$\left(\mathrm{g} \mathrm{kg}^{-1}\right)$ & $(1.5)$ & $(0.5)$ & $(0.9)$ \\
\hline $\mathrm{NH}_{4}^{+}$ & $0.67^{\mathrm{a}}$ & $0.64^{\mathrm{a}}$ & $0.46^{\mathrm{b}}$ \\
\hline$\left(\mathrm{g} \mathrm{kg}^{-1}\right)$ & $(0.05)$ & $(0.03)$ & $(0.01)$ \\
\hline $\mathrm{NO}_{3}^{-}$ & $7.08^{\mathrm{a}}$ & $7.28^{\mathrm{a}}$ & $4.68^{b}$ \\
\hline$\left(\mathrm{g} \mathrm{kg}^{-1}\right)$ & $(0.9)$ & $(1.2)$ & $(0.6)$ \\
\hline $\mathrm{NO}_{2}^{-}$ & $14.96^{\mathrm{b}}$ & $13.33^{\mathrm{b}}$ & $20.04^{\mathrm{a}}$ \\
\hline$\left(\mathrm{g} \mathrm{kg}^{-1}\right)$ & $(1.3)$ & $(1.2)$ & $(1.8)$ \\
\hline $\mathrm{Na}^{+}$ & $0.56^{\mathrm{a}}$ & $0.47^{\mathrm{b}}$ & $0.53^{\mathrm{b}}$ \\
\hline$\left(\mathrm{g} \mathrm{kg}^{-1}\right)$ & $(0.12)$ & $(0.14)$ & $(0.13)$ \\
\hline $\mathrm{Ca}^{++}$ & $13.5^{\mathrm{a}}$ & $9.7^{\mathrm{b}}$ & $14.0^{\mathrm{a}}$ \\
\hline$\left(\mathrm{g} \mathrm{kg}^{-1}\right)$ & $(4.5)$ & (3.8) & $(4.2)$ \\
\hline $\mathrm{Mg}^{++}$ & $0.98^{\mathrm{a}}$ & $0.51^{\mathrm{b}}$ & $0.45^{\mathrm{b}}$ \\
\hline$\left(\mathrm{g} \mathrm{kg}^{-1}\right)$ & $(0.22)$ & $(0.44)$ & $(0.20)$ \\
\hline
\end{tabular}

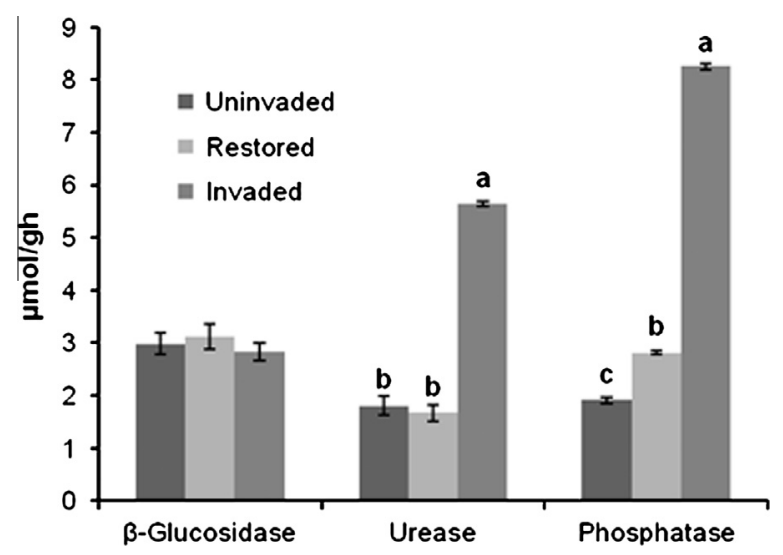

Fig. 5. Extracellular enzymatic activities in non-invaded, restored and invaded soils. Different letters indicate significant differences at $5 \%$ level, tested by Student's t-test. Error bars denote standard errors.

invaded areas in comparison to non-invaded areas $\left(0.7 \mathrm{mgNaCl} \mathrm{g}^{-1}\right.$ vs $0.5 \mathrm{mgNaCl} \mathrm{g}^{-1}$ ) may be due to the accumulation of seaweed and marine debris (with salt accumulation) between the leaves of the invasive plant (Novoa, personal observation). Our results revealed a larger amount of nitrite in non-invaded soils compared to invaded soils. Invaded soils have a higher content of decaying organic matter, which contains large amounts of nitrogen. This suggests that the ammonium derived from the decomposition process rapidly undergoes the entire process of nitrification, favored by $\mathrm{pH}$ close to neutrality (Bothe et al., 2006), and the nitrate derivatives would be rapidly accumulated by $C$. edulis plants. However, in non-invaded soils there is less of the decomposing plant debris, and the released nitrite, due to the basic soil reaction, could be transformed into nitrate at a lower rate than in invaded soils. Moreover, non-invaded soils present more volatilization of $\mathrm{NO}_{3}$ due to the higher pH levels (Jones et al., 2007). Thus, non-invaded soils accumulate a large amount of nitrite.

Phosphorus is the second most important nutrient in the coastal dunes, and $\mathrm{pH}$ directly influences its availability: at high $\mathrm{pH}$, the phosphorus released precipitates as salts (Fisher et al., 2006). As the $\mathrm{pH}$ decreases, phosphorus availability increases to a maximum of between pH 6.8 and 7.2 (Grootjans et al., 2004). The results of our analysis of the total and available phosphorus indicate a greater amount in the invaded soil than in non-invaded soil. This can be explained both by the input of organic matter from C. edulis, and by the influence of $\mathrm{pH}$ on the availability of this nutrient.

\subsection{Effect of $C$. edulis invasion on the performance of native dune species}

Novoa and González (unpublished), found the total germination and germination rate of $M$. littorea seedlings to be stimulated by a lower salinity level, and the latter measure also by lower levels of nutrients in the soil. As pointed out above, salinity and nutrients were lower in non-invaded than invaded soils. A high salt content can block the germination process by osmotic effect, drawing water from seeds (Bubel, 1988). The stimulation by the lower nutrient condition is a common response on dune species (Maun, 2009). In fact, the selection process has favored the emergence of mechanism that allows seeds to 'feel' their neighbors (Tielbörger and Prasse, 2009).

When $C$. edulis invades coastal habitats, it builds up a deep litter layer where chemicals from the dried succulent leaves may leach into the soil (D'Antonio \& Mahall, personal communication). This could be the reason for the $50 \%$ decrease in $M$. littorea survival in C. edulis patches, found in our study. This corresponds to the fact that changes in the soil due to $C$. edulis invasion are known to prevent establishment of native species (D'Antonio and Mahall, 1991; Conser and Connor, 2008; Donath and Eckstein, 2009). In addition, many ruderal, opportunistic species can establish in invaded soils. Thus, the decrease in $M$. littorea survival could be due to both the competition with the ruderal species and to the chemicals leached from $C$. edulis litter during decomposition. The growth of $M$. littorea 
was, however, reduced on $C$. edulis-affected soil only at initial stages of plant development; once plants are established, the effect of soils on growth disappears. From the restoration viewpoint it is important that the survival and growth of $M$. littorea was not improved by transplanting seedlings, compared to plants growing from seed.

\subsection{Plant diversity on restored areas and the role of ruderal species}

There is a growing body of evidence that invasive plant species indeed negatively affect native plant species richness and composition (Gerber et al., 2008; Reid et al., 2009). The decrease in species diversity in post-invasion sites is further manifest by the more pronounced reduction in numbers of species than individuals on invaded sites. Therefore, invaded areas are recolonized by fewer but more abundant species.

Our results indicate that the mechanisms underlying this pattern could be related to the 'novel weapons' hypothesis throughout litter decomposition (Callaway and Ridenour, 2004). Overall, plant litter can have both positive (Xiong and Nilsson, 1999) and negative (Singh et al., 1999) effects on growth and regeneration of plant species. In our system, the germination of typical dune species is enhanced by the litter of $C$. edulis, but once they reach the seedlings stage, their establishment deteriorated or was even prevented. But, ruderal species are not affected by the litter of $C$. edulis, probably due to their greater plasticity that contributes to their opportunistic strategy. This suggests that the presence of the $C$. edulis litter on coastal dune ecosystems promotes the success of ruderal species and constrains the establishment of native dune species.

The effect of litter interacts with plant competitive relationships, which also contribute to the prevalence of ruderal species over typical dune species in invaded areas. The ruderal species tested in our study reduced radicle growth of the typical dune species $M$. littorea; this could result in restricted access of Malcolmia plants to the scarce resources present in the dune soil (Olff et al., 1993). The competitive interactions we found were species-dependent (Callaway and Walker, 1997). Scolymus always had a significant detrimental effect on some ecophysiological parameters (germination and early growth) of Malcomia, while the effect of Dactylis was only marginal (Table 3 ). The detrimental effects of ruderal species on the native $M$. littorea were more pronounced on soil from invaded areas, whether or not the litter was present; the ruderal species establish more easily on these soils due to the higher contents of organic matter, and more favorable $\mathrm{pH}$ (Antonio, 1993). That C. maritima, another dune species tested, was not influenced by competition with ruderal species (results not shown) indicates that the effects of ruderal species establishing in invaded areas are species specific and/or act at different stages of native species' life cycles (Rousset and Lepart, 2000).

\subsection{Implications for restoration}

In the study area, ruderal species are favored by modified soil characteristics attenuating hard coastal physical conditions, presence of $C$. edulis litter, and their competitive superiority over native species under such conditions (see above). From the restoration point of view, the establishment of individuals of the native species $M$. littorea is the key population development phase, as it is where plants are negatively affected by ruderal competitors.

Changes in dune soil properties and microbial communities due to invasion have differed in their dynamics over time; it was shown that one of the reasons for ruderal species success was that chemical properties rather important to plant ecology and distribution, such as $\mathrm{pH}$, organic matter contents or nitrates, persisted at the same level in the first year after the treatment, a period that is crucial for initial establishment of the studied plant species. On the other hand, there was an obvious tendency for restored soils to follow a trajectory toward pre-invasion conditions, and this was true for many soil parameters, some of which seem to be fully restored after 1 year. The same trend is indicated for the microbial community, inferring from the dynamics of enzymatic activities. Our results showed that the desired direction of natural regeneration of soil can be speeded up by removing litter from restored sites, combined with over-seeding of appropriate typical dune species. As the survival and growth of $M$. littorea plants did not improve when seedlings were transplanted, restoration could rely on sowing seed instead of transplanting plants; this method is easier and cheaper.

Overall, our study strongly implies that if restoration actions only aim at the removal of the invader, as has been done so far with C. edulis in the study region, the plant species diversity of the restored area will probably remain markedly lower than in natural, non-invaded areas, not achieving the ultimate goal of dune restoration. Because of the rather uniform characteristics of dune ecosystems (Maun, 2009), it is reasonable to assume that areas invaded by $C$. edulis are likely to respond in the similar way as our studied area. Therefore, to restore successfully the dune ecosystems invaded by $C$. edulis, as it was shown for other invasive species (Ghorbani et al., 2006), it is crucial to (i) remove not only the living parts of the invasive species, but also the litter, (ii) overseed the restored areas with appropriate native dune species, and (iii) follow up to remove opportunistic ruderal species that are likely to constrain the establishment of the sown species, and colonization by other typical dune species.

\section{Acknowledgements}

AN was supported by the 'grant to encourage mobility of visiting professors and students under institutional strategies of doctoral training in universities and consolidation of doctoral programs with mention to Excellence' of the Ministry of Education of Spain. PP and LM were supported by Grant no. GA206/09/0563 and long-term research development Project no. RVO 67985939 (both from the Academy of Sciences of the Czech Republic). PP was also supported by institutional resources of Ministry of Education, Youth and Sports of the Czech Republic, and acknowledges the support by Praemium Academiae award from the Academy of Sciences of the Czech Republic.

\section{References}

Albert, M., 1995. Portrait of an invader II: the ecology and management of Carpobrotus edulis. California Exotic Pest Plant Council 3, 4-6.

Allen, S.E., 1989. Chemical analysis of ecological materials. Blackwell Scientific Publications.

Allison, S.D., Vitousek, P.M., 2005. Responses of extracellular enzymes to simple and complex nutrient inputs. Soil Biol. Biochem. 37, 937-944.

Analíticos, C.de métodos, 1973. Determinaciones analíticas en suelos. Normalización de métodos. Anales de Edafología y Agrobiología 32, 11-51.

Andreu, J., Vilà, M., 2007. Análisis de la gestión de las plantas exóticas en los espacios naturales españoles. Ecosistemas 3, 1-16.

Antonio, C.M.D., 1993. Mechanisms controlling invasion of coastal plant communities by the alien succulent Carpobrotus edulis. Ecology 74, 83-95.

Bakker, J.D., Wilson, S.D., 2004. Using ecological restoration to constrain biological invasion. J. Appl. Ecol. 41, 1058-1064.

Bartomeus, I., Bosch, J., Vilà, M., 2008. High invasive pollen transfer, yet low deposition on native stigmas in a Carpobrotus-invaded community. Ann. Botany 102, 417-424.

Bothe, H., Ferguson, S.J., Newton, W.E., 2006. Biology of the nitrogen cycle. Elsevier, Amsterdam.

Bray, R., Kurtz, L., 1945. Determination of total, organic, and available forms of phosphorus in soils. Soil Sci. 59, 39-45.

Bubel, N., 1988. The New Seed-starters Handbook. Rodale Press, Inc.

Callaway, R.M., Ridenour, W.M., 2004. Novel weapons: invasive success and the evolution of increased competitive ability. Front. Ecol. Environ. 2, 436-443.

Callaway, R.M., Walker, L.R., 1997. Competition and facilitation: a synthetic approach to interactions in plant communities. Ecology 78, 1958-1965.

Carranza, M.L., Ricotta, C., Carboni, M., Acosta, A.T.R., 2011. Habitat selection by invasive alien plants: a bootstrap approach. Preslia 83, 529-536. 
Conser, C., Connor, E.F., 2008. Assessing the residual effects of Carpobrotus edulis invasion, implications for restoration. Biol. Invasions 11, 349-358.

Council Directive 92/43/EEC, of 21 May 1992 on the conservation of natural habitats and of wild fauna and flora.

Cox, R.D., Allen, E.B., 2008. Stability of exotic annual grasses following restoration efforts in southern California coastal sage scrub. J. Appl. Ecol. 45, 495-504.

Daehler, C.C., 2012. Performance comparisons of co-occurring native and alien invasive plants: implications for conservation and restoration. Annu. Rev. Ecol. Evol. Syst. 34, 183-211.

D'Antonio, C., Mahall, B.E., 1991. Root profiles and competition between the invasive, exotic perennial, Carpobrotus edulis, and two native shrub species in California coastal scrub. Am. J. Bot. 78, 885-894.

D’Antonio, C., Meyerson, L.a., 2002. Exotic plant species as problems and solutions in ecological restoration: a synthesis. Restor. Ecol. 10, 703-713.

Donath, T.W., Eckstein, R.L., 2009. Effects of bryophytes and grass litter on seedling emergence vary by vertical seed position and seed size. Plant Ecol. 207, 257268.

Fisher, J., Veneklaas, E., Lambers, H., Loneragan, W., 2006. Enhanced soil and leaf nutrient status of a Western Australian Banksia woodland community invaded by Ehrharta calycina and Pelargonium capitatum. Plant Soil 284, 253-264.

Gaertner, M., Den Breeyen, a., Richardson, D.M., 2009. Impacts of alien plant invasions on species richness in Mediterranean-type ecosystems: a metaanalysis. Prog Phys Geog 33, 319-338.

Gallagher, K.G., Schierenbeck, K.A., D'Antonio, C.M., 1997. Hybridization and introgression in Carpobrotus spp. (aizoaceae) in California ii. Allozyme evidence. Am. J. Bot. 84, 905-911.

GEIB, 2006. Top 20: las 20 especies exóticas invasoras más dañinas presentes en España. GEIB, Serie Técnica 2, 116.

Gerber, E., Krebs, C., Murrell, C., Moretti, M., Rocklin, R., Schaffner, U., 2008. Exotic invasive knotweeds (Fallopia spp.) negatively affect native plant and invertebrate assemblages in European riparian habitats. Biol. Conserv. 141, 646-654.

German, D.P., Weintraub, M.N., Grandy, a.S., Lauber, C.L., Rinkes, Z.L., Allison, S.D. 2011. Optimization of hydrolytic and oxidative enzyme methods for ecosystem studies. Soil Biol. Biochem. 43, 1387-1397.

Ghorbani, J., Le Duc, M.G., McAllister, H.A., Pakeman, R.J., Marrs, R.H., 2006. Effects of the litter layer of Pteridium aquilinum on seed banks under experimental restoration. Appl. Veg. Sci. 9, 127-136.

Gioria, M., Pysek, P., Moravcová, L., 2012. Soil seed banks in plant invasions: promoting species invasiveness and long-term impact on plant community dynamics. Preslia 84, 327-350.

Gobierno del principado de Asturias, 1995. Decreto 65/1995, de 27 de abril, por el que se crea el Catálogo Regional de Especies Amenazadas de la Flora del Principado de Asturias y se dictan normas para su protección (BOPA 5/6/1995)

Gooding, E.G.B., 1947. Ados, observations on the sand dunes of Barbados, British West Indies. J. Ecol. 34, 111-125.

Gordon, D.R., 1998. Effects of invasive, non-indigenous plant species on ecosystem processes: lessons from Florida. Ecol. Appl. 8, 975-989.

Grime, J.P., 1997. Ecology: biodiversity and ecosystem function: the Debate Deepens. Science 277, 1260-1261.

Grootjans, A.P., Adema, E.B., Bekker, R.M., Lammerts, E.J., 2004. Why young coastal dune slacks sustain a high biodiversity. In: Martínez, M.L., Psuty, N. (Eds.), Ecologycal Studies. Springer, pp. 85-101.

Guitián, F., Carballas, T., 1976. Ténicas de análisis de suelos. Pico Sacro, Santiago de compostela.

Hartmann, H.E.K., 2002. Illustrated Handbook of Succulent Plants: Aizoaceae A-E. Springer.

Hulme, P.E., Pyšek, P., Winter, M., 2012. Biosecurity on thin ice in Antarctica. Science (New York, N.Y.) 336, 1102, 1104.

Hussain, M.I., González-Rodríguez, L., Reigosa, M.J., 2008. Germination and growth response of four plant species to different allelochemicals and herbicides. Allelopathy J. 22, 101-110.

Jakmunee, J., Junsomboon, J., 2009. Determination of available phosphorus in soils by using a new extraction procedure and a flow injection amperometric system. Talanta 79, 1076-1080.

Jander, G., 1961. Análisis Volumétrico. Editorial hispanoamericana.

Jones, B.C.A., Koenig, R.T., Ellsworth, J.W., Brown, B.D., Jackson, G.D., 2007. Management of Urea Fertilizer to Minimize Volatilization. MSU Extension, pp. $1-12$.

Kandeler, E., Gerber, H., 1988. Short-term assay of soil urease activity using colorimetric determination of ammonium. Biol. Fert. Soils 6, 68-72.

Kempers, A.J., 1974. Determination of sub-microquantities of ammonium and nitrates in soils with fenol, sodium nitroprusside and hypochlorite. Geoderma 12, 201-206

Kettunen, M., Genovesi, P., Gollasch, S., Pagad, S., Starfinger, U., 2009. Technical support to EU strategy on invasive alien species (IAS) assessment of the impacts of IAS in Europe and the EU. IEEP, Brussels.

Konova, M., 1966. Soil organic matter: its nature, its role in soil formation and in soil fertility. Pergamon Press.

Läuchli, A., Grattan, S.R., 2007. Plant growth and development under salinity stress. In: Jenks, M.A., (Ed.), Advances in Molecular Breeding Toward Drought and Salt Tolerant Crops and Salt Tolerant, Crops. pp. 1-32.

Lichter, J., 1998. Primary succession and forest development on coastal lake Michigan sand dunes. Ecol. Monogr. 68, 487-510.

Ljungdahl, L.G., Eriksson, K.-E., 1985. Ecology of microbial cellulose degradation. Adv. Microbiol. Ecol. 8, 237-299.
Lortie, C.J., Cushman, J.H., 2007. Effects of a directional abiotic gradient on plant community dynamics and invasion in a coastal dune system. J. Ecol. 95, 468481.

Magurran, A., 1988. Ecological Diversity and its Measurement. Princeton University Press, Princeton, New Jersey.

Maun, M.A., 2009. The Biology of Coastal Sand Dunes. Oxford University Press.

Maurel, N., Salmon, S., Ponge, J.-F., Machon, N., Moret, J., Muratet, A., 2009. Does the invasive species Reynoutria japonica have an impact on soil and flora in urban wastelands? Biol. Invasions 12, 1709-1719.

McConnachie, M.M., Cowling, R.M., Van Wilgen, B.W., McConnachie, D.a., 2012. Evaluating the cost-effectiveness of invasive alien plant clearing: a case study from South Africa. Biol. Conserv. 155, 128-135.

Novoa, A., González, L., Moravcová, L., Pyšek, P., 2012. Effects of soil characteristics, allelopathy and frugivory on establishment of the invasive plant Carpobrotus edulis and a co-occuring native, Malcolmia littorea. PLoS ONE 7, 1-11.

Olff, H., Huisman, J., Van Tooren, B., 1993. Species dynamics and nutrient accumulation during early primary succession in coastal sand dunes. J. Ecol. 81, 693-706.

Pancholy, S.K., Rice, E.L., 1973. Soil enzymes in relation to old field succession: amylase, cellulase, invertase, dehydrogenase, and urease1. Soil Sci. Soc. Am. J. $37,47$.

Pimentel, D., Zuniga, R., Morrison, D., 2005. Update on the environmental and economic costs associated with alien-invasive species in the United States. Ecol. Econ. 52, 273-288.

Pysek, P., Richardson, D.M., 2010. Invasive species, environmental change and management, and health. Annu. Rev. Environ. Resour. 35, 25-55.

Pysek, P., Richardson, D.M., Pergl, J., Jarosík, V., Sixtová, Z., Weber, E., 2008. Geographical and taxonomic biases in invasion ecology. Trends Ecol. Evol. 23, 237-244.

Pyšek, P., Chytrý, M., Pergl, J., Sádlo, J., Wild, J., 2012a. Plant invasions in the Czech Republic: current state, introduction dynamics, invasive species and invaded habitats. Preslia 84, 575-629.

Pyšek, P., Jarošík, V., Hulme, P.E., Pergl, J., Hejda, M., Schaffner, U., Vilà, M., 2012b. A global assessment of invasive plant impacts on resident species, communities and ecosystems: the interaction of impact measures, invading species' traits and environment. Glob. Change Biol. 18, 1725-1737.

Reid, A.M., Morin, L., Downey, P.O., French, K., Virtue, J.G., 2009. Does invasive plant management aid the restoration of natural ecosystems? Biol. Conserv. 142, 2342-2349.

Richardson, D.M., Pys, P., 2006. Plant invasions: merging the concepts of species invasiveness and community invasibility. Prog. Phys. Geog. 30, 409-431.

Rousset, O., Lepart, J., 2000. Positive and negative interactions at different life stages of a colonizing species (Quercus humilis). J. Ecol. 88, 401-412.

Salas, F., Neto, J., Borja, A., Marques, J., 2004. Evaluation of the applycability of a marine biotic index to characterize the status of estuarine ecosystems: the case of Mondego estuary (Portugal). Ecol Indic 4, 215-225.

Saña Vilaseca, J., 1996. La gestión de la Fertilidad de los Suelos. MAPA.

Selge, S., Fischer, A., Van der Wal, R., 2011. Public and professional views on invasive non-native species - a qualitative social scientific investigation. Biol. Conserv. 144, 3089-3097.

Simberloff, D., Parker, I.M., Windle, P.N., 2005. Introduced species policy, management, and future research needs. Front. Ecol. Environ. 3, 12-20.

Simberloff, D., Martin, J.-L., Genovesi, P., Maris, V., Wardle, D.a, Aronson, J., Courchamp, F., Galil, B., García-Berthou, E., Pascal, M., Pyšek, P., Sousa, R. Tabacchi, E., Vilà, M., 2012. Impacts of biological invasions: what's what and the way forward. Trends Ecol. Evol., 1-9.

Singh, H.P., Batish, D.R., Kohli, R.K., 1999. Autotoxicity: concept, organisms, and ecological significance. CRC Crit. Rev. Plant Sci. 18, 757-772.

Speir, T., Ross, D., 1978. Soil phosphatase and sulphatase. In: Burns, R. (Ed.), Soil Enzymes. Academic Press, San Diego, pp. 197-250.

Stege, P., Messina, G., Bianchi, G., Olsina, R., Raba, J., 2009. Determination of arylsulphatase and phosphatase enzyme activities in soil using screen-printed electrodes modified with multi-walled carbon nanotubes. Soil Biol. Biochem. 41, 2444-2452.

Sumner, M.E., Miller, W.P., 1996. Cation exchange coefficients. In: Birgham, J.M. (Ed.), Methods of Soil Analysis: Part 3. Chemical, Methods, pp. 12011229.

Tabatabai, M.a., Bremner, J.M., 1969. Use of p-nitrophenyl phosphate for assay of soil phosphatase activity. Soil Biol. Biochem., 301-307.

Tielbörger, K., Prasse, R., 2009. Do seeds sense each other? Testing for densitydependent germination in desert perennial plants. Oikos 118, 792-800.

Turner, B.L., 2010. Variation in pH optima of hydrolytic enzyme activities in tropical rain forest soils. Appl. Environ. Microbiol. 76, 6485-6493.

Vilà, M., D'Antonio, C., 1998. Fruit choice and seed dispersal of invasive vs. noninvasive Carpobrotus (Aizoaceae) in coastal California. Ecology 79, 10531060.

Vosse, S., Esler, K.J., Richardson, D.M., Holmes, P.M., 2008. Can riparian seed banks initiate restoration after alien plant invasion? Evidence from the Western Cape, South Africa. South African J. Bot. 74, 432-444.

Watling, J.I., Hickman, C.R., Orrock, J.L., 2011. Invasive shrub alters native forest amphibian communities. Biol. Conserv. 144, 2597-2601.

Weber, E., D'Antonio, C.M., 2000. Phenotypic plasticity in hybridizing Carpobrotus spp. (Aizoaceae) from coastal California and its role in plant invasion. Can. J. Bot. 77, 1411-1418.

Xiong, S., Nilsson, C., 1999. The effects of plant litter on vegetation: a meta-analysis. J. Ecol. 87, 984-994. 